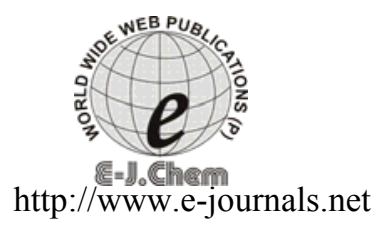

ISSN: 0973-4945; CODEN ECJHAO

E-Journal of Chemistry

2011, 8(S1), S19-S26

\title{
Kinetic Study of Photocatalytic Degradation of Tolonium Chloride Under High Pressure Irradiation in Aquatic Buffer Systems
}

\author{
M. MONTAZEROZOHORI*, S. NEZAMI and S. MOJAHEDI \\ Chemistry Department \\ Yasouj University, Yasouj, 75914-353, Iran \\ mmzohory@yahoo.com
}

Received 6 January 2011; Accepted 1 March 2011

\begin{abstract}
Anatase titanium dioxide catalyzed photodegradation of tolonium chloride at various bufferic $\mathrm{pH}$ of 2, 7, 9 and 12 in aqueous solution is presented. The effect of some physicochemical parameters such as initial concentration of dye, catalyst amount and reaction time on photocatalytic degradation has been investigated in a photo-reactor cell containing high pressure mercury lamp to obtain the optimum conditions in each bufferic $\mathrm{pH}$ at constant temperature. A complete spectrophotometric kinetic study of tolonium chloride under high pressure irradiation at buffer media was performed. The photocatalytic degradation observed rate constants $\left(\mathrm{k}_{\mathrm{obs}}\right)$ were found to be $2.90 \times 10^{-3}, 3.30 \times 10^{-3}, 3.20 \times 10^{-3}$ and $5.20 \times 10^{-3} \mathrm{~min}^{-1}$ for buffer $\mathrm{pH}$ of 2-12 respectively. It was found that a pseudo-first-order kinetic model based on Langmuir-Hinshelwood one is usable to photodegradation of this compound at all considered buffer $\mathrm{pH}$. In addition to these, the LangmuirHinshelwood rate constants, $k_{r}$ for the titled compound at various $\mathrm{pH}$ are reported.
\end{abstract}

Keywords: Degradation, Tolonium chloride, Photocatalytic, Anatase titanium dioxide

\section{Introduction}

It is well known that some dyes and degradation products are highly toxic and carcinogenic. The removal of pollutant compounds from aqueous media can be done using various techniques including biological treatments such as biofiltration and bioscrubbing; physical absorption methods for example use of activated carbon adsorption and destructive process such as wet chemical scrubbing, thermal oxidation, water hydrolysis by aqueous alkalis and oxidative chlorination $^{1-9}$. Each of these processes has some advantages, but production of large volumes of toxic solutions or toxic gaseous derivatives is one common disadvantage of 
them that need next treatments. Heterogeneous photocatalysis based on the use of suitable semiconductor materials is known as another destructive technical process leading to the efficient degradation and in most cases the complete mineralization of a variety of organic or inorganic toxic pollutants present at aqueous waste waters. Among semiconductor oxides, titanium dioxide is the most applicable one because of some its properties such as stability and non-toxicity ${ }^{10-14}$. Therefore the use of $\mathrm{TiO}_{2}$ as photocatalyst for the degradation of organic pollutants in water has been found as a highly promising universal method in the economically and environmental friendly processes point of view ${ }^{15}$. Previously photocatalytic decomposition of tolonium chloride in the presence degussa-type titanium dioxide under medium pressure mercury lamp irradiation at non-bufferic system has been reported ${ }^{16}$. In continuation of our previous works ${ }^{17-20}$ in this work kinetic study of photodegradation of tolonium chloride (also known as Toluidine Blue) in the presence of anatase titanium dioxide under high pressure mercury lamp at various buffer system is described and compared with previous reported conditions.

\section{Experimental}

All compounds were purchased from Merck and Aldrich. Anatase titanium dioxide(99.9\%) was analytical grade. The $\mathrm{pH}$ of solution was adjusted using diluted aqueous buffers that were prepared by the following compounds: $\mathrm{KH}_{2} \mathrm{PO}_{4}, \mathrm{Na}_{2} \mathrm{HPO}_{4}, \mathrm{NaOAc}, \mathrm{HOAc}, \mathrm{Na}_{2} \mathrm{~B}_{4} \mathrm{O}_{7}$, $\mathrm{HCl}, \mathrm{H}_{2} \mathrm{SO}_{4}$ and $\mathrm{NaOH}$. In all experiments doubly distilled water was used

\section{Apparatus}

Photochemical set containing 400W high pressure mercury lamp was used for photodegradation experiments. UV- VIS spectrophotometer, JASCO-V570, was used for spectral monitoring of tolonium chloride concentrations. A parsazma SH-12 model of centrifuge was used for separation of photocatalysts from solution. Metrohm -620 model of $\mathrm{pH}-$ meter was applied for controlling of $\mathrm{pH}$ of solution.

\section{Analytical determinations}

Spectrophotometric method was used for determination of concentration of tolonium chloride via calibration curves at $\lambda_{\max }=588,590,588$ and $580 \mathrm{~nm}$ for buffer pHs of 2, 7, 9 and 12 repectively.

\section{General procedure for photodegradation process}

The photodegradation experiments were performed by irradiation of $20 \mathrm{~mL}$ of 70 and/or $80 \mathrm{ppm}$ oxygenated (5 minutes bubbled) and stirred aqueous solution of tolonium chloride as well as considered amounts of photocatalysts in photoreactor cell under $400 \mathrm{~W}$ high pressure mercury lamp at room temperature. After requested time for photodegradation, photocatalyst was separated by centrifugation and photolyte was analyzed by UV-Vis spectrophotometric method.

\section{Results and Discussion}

Photocatalytic decomposition of a pollutant by use of a photocatalyst in presence of UV irradiation is illustrated by the mechanism ${ }^{21}$ shown in Scheme 1 . The mechanism indicate that UV radiation, transfer one electron from conduction band to the valence band of the photocatalyst generating electron/hole $\left(\mathrm{e}^{-} / \mathrm{h}^{+}\right)$pairs. The $\mathrm{e}^{-} / \mathrm{h}^{+}$pairs produce active oxidant species such as hydroxyl radicals, superoxide anion radicals and hydrogen peroxide that degrade target molecules (D) into decomposed products $(\mathrm{P})$ : 


$$
\begin{gathered}
\mathrm{TiO} 2+\mathrm{h} v \rightarrow e^{-}+h^{+} \\
\mathrm{h}^{+}+\mathrm{H}_{2} \mathrm{O}\left(\mathrm{TiO}_{2}\right) \rightarrow \bullet \mathrm{OH}\left(\mathrm{TiO}_{2}\right)+\mathrm{H}^{+} \\
\mathrm{h}^{+}+\mathrm{OH}(\mathrm{TiO} 2)^{-} \leftarrow \bullet \mathrm{OH}\left(\mathrm{TiO}_{2}\right) \\
\mathrm{e}^{-}+\mathrm{O} 2 \rightarrow \mathrm{O}_{2}^{\cdot-} \\
\mathrm{O}_{2}^{\cdot-}+\mathrm{HO}^{\bullet}+\mathrm{H}^{+} \rightarrow \mathrm{H}_{2} \mathrm{O}_{2}+\mathrm{H}^{+} \rightarrow \mathrm{H}_{2} \mathrm{O}_{2}+\mathrm{O}_{2} \\
\cdot \mathrm{OH}\left(\mathrm{TiO}_{2}\right)+\mathrm{D} \rightarrow \text { intermediates } \rightarrow \mathrm{P}
\end{gathered}
$$

After introductorily expression about the phocatalytic processes, the effect of effectual parameters and kinetics model in photocatalytic degradation of titled compound is presented in the next sections. By designing the blank experiments, it was found that degradation percents in the presence of agents such as photocatalyst, oxygen and irradiation simultaneously were non-comparable with those ones that each one of above agents is absence. Therefore at first, optimization of parameters was done in the presence of these three agents and then kinetic study performed.

\section{Calibration curves for the standard solutions}

Tolonium chloride is chemically stable in the range buffer $\mathrm{pH}, 2-12$ therefore the standard solutions with the range of 0-100 ppm of tolonium chloride at buffer $\mathrm{pH}$ of 2, 7, 9 and 12 were prepared. Then the plots of absorbance versus concentration at $\lambda_{\max }$ were drawn in Figure 1.

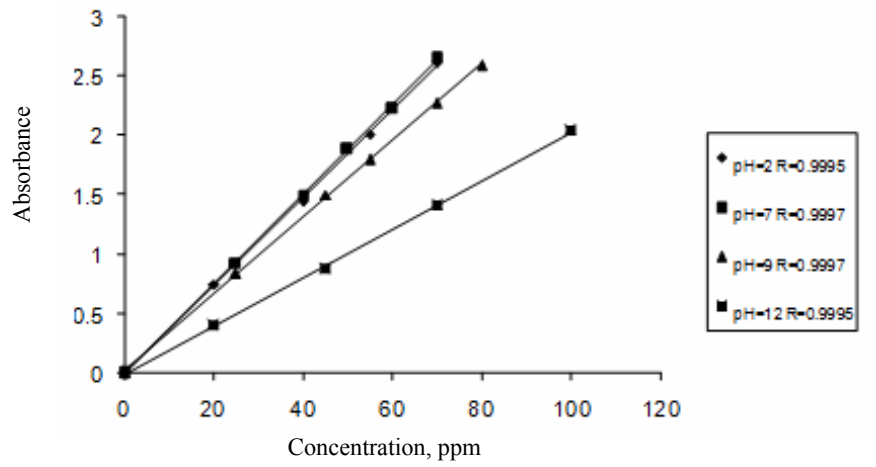

Figure 1. Calibration curve of tolonium chloride at buffer $\mathrm{pH}$ of 2, 7, 9 and 12

\section{Optimization of anatase titanium dioxide loading on residual concentration}

Decomposition of the compounds takes place on both active surface of the catalyst particles followed by adsorption and in bulk solution by phocatalyst generated active oxidant species. Therefore photocatalyst loading has an important role in decomposition. In our conditions, the effect of the catalyst loading has been presented by the plotting of residual concentration of tolonium chloride in each buffer $\mathrm{pH}$ after photodecomposition using various amounts of anatase titanium dioxide within the same reaction times. The plots are shown in Figure 2. As seen in the Figure 2, the amount of 30, 40, 40 and $20 \mathrm{mg}$ were found to be optimum amount of catalyst at $\mathrm{pH}$ of 2, 7, 9 and 12 respectively for effective degradation of compound and higher amounts decrease the percent of degradation due to high scattering of UV-light by dispersed catalyst and therefore low formation of active sites and oxidant species ${ }^{22-23}$. It is to be noted that the optimum amount of photocatalyst is different at various buffer $\mathrm{pH}$. This observation reveals that catalyst dispersion is different at various $\mathrm{pH}$. It seems that in our conditions, dispersion at high acidic and high basic media is more than two other $\mathrm{pH}$, 
so that the lower the amount of photocatalyst is optimum in these $\mathrm{pH}$. In previous report ${ }^{16}$ the effect of catalyst (Degussa titanium dioxide) loading only at non-bufferic $\mathrm{pH}$ of 5 has been reported that amount of $1 \mathrm{~g} / \mathrm{L}$ catalyst was selected as optimum. In this work the higher amounts of catalyst for buffer $\mathrm{pH} \mathrm{2,} \mathrm{7,9} \mathrm{and} \mathrm{the} \mathrm{same} \mathrm{amount} \mathrm{are} \mathrm{optimum} \mathrm{for} \mathrm{effective}$ degradation. Other bufferic $\mathrm{pH}$ were not investigated because the lack of a suitable absorption wavelength for spectrophotometric analysis and monitoring.

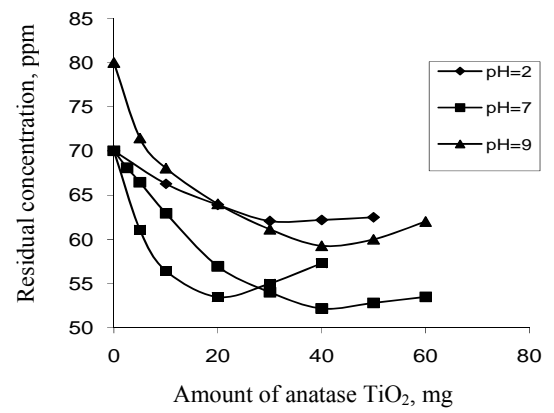

Figure 2. The effect of anatase titanium dioxide loading on residual concentration of tolonium chloride after irradiation(Time $=60 \mathrm{~min} . \mathrm{V}=20 \mathrm{~mL}$ )

The effect of bufferic $p H$

Photodegradation of tolonium chloride in the presence of anatase titanium dioxide was affected by $\mathrm{pH}$ of the solution. The results as depicted in Figure 3 shows the more dye degradation was found to be at buffer $\mathrm{pH}=9$ when the dye concentration is $40 \mathrm{ppm}$ and catalyst amount is $40 \mathrm{mg}$. This result can be explained based on adsorption mechanism under the influence of initial solution $\mathrm{pH}$. Titanium dioxide usually has an isoelectric point of charge at a $\mathrm{pH}$ about 6.8 , its surface has a positive charge at $\mathrm{pHs}$ lower than 6.8 via protonation and a negative charge at $\mathrm{pHs}$ higher than 6.8 via deprotonation. It seems that among the $\mathrm{pH} 2,7,9$ and 12; at $\mathrm{pH}=9$, there are more dye adsorption on or migration to near the catalyst surface favorable due to electrostatic interaction between tolonium chloride as cationic dye and catalyst. On the other hand, it is to be noted that in more alkaline solution ${ }^{\circ} \mathrm{OH}$ is easier to be generated by oxidizing of more hydroxide ions available on photocatalyst surface that diffuse to bulk solution leading to more effective photodegradation at basic medium ${ }^{24}$. But also as will be seen in the next section when the optimum amount of catalyst at each $\mathrm{pH}$ is used, the higher photodegradation rate obtained at buffer $\mathrm{pH}=12$. This trend also was observed in previous report when degussa titanium dioxide has been used at non-buffer $\mathrm{pH}$.

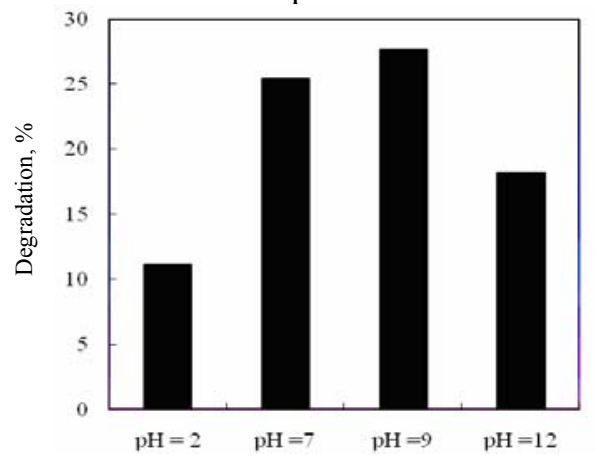

Figure 3. The effect of bufferic $\mathrm{pH}$ on $\%$ photodegradation (Anatase $\mathrm{TiO}_{2}: 40 \mathrm{mg} ; \mathrm{V}=20 \mathrm{~mL}$; irradiation time $=60 \mathrm{mim}$ ) 


\section{Kinetics study}

The plots of residual concentration-time of tolonium chloride for each buffer $\mathrm{pH}$ using optimum amount of anatase titanium dioxide as mentioned in section 2.2 are drawn in Figure 4. As shown in this Figure for $\mathrm{pH}$ of 2, 7 and 9, the dye residual concentration reach to very low value after about 750 minutes while it is occurred after 500 minutes at $\mathrm{pH}=12$. In compared with degussa titanium dioxide catalyzed degradation at non buffer $\mathrm{pH}^{16}$, anatase titanium dioxide catalyses degradation after longer times. This can be related to both lower catalytic activity and bufferic conditions of medium during the reaction. The photodegradation of Tolonium chloride at bufferic $\mathrm{pH}$ obeys the pseudo-first order kinetics:

$$
\frac{-d c}{d t}=k c
$$

Where $c$ is the concentration of Tolonium chloride and $k$ is the observed first-order rate constant $\left(\mathrm{k}_{\mathrm{obs}}\right)$. From the integration of this equation, the concentration-time equation of $\ln \left(\mathrm{C}_{0} / \mathrm{C}_{\mathrm{t}}\right)=\mathrm{k}_{\text {obs }}$ will be derived.

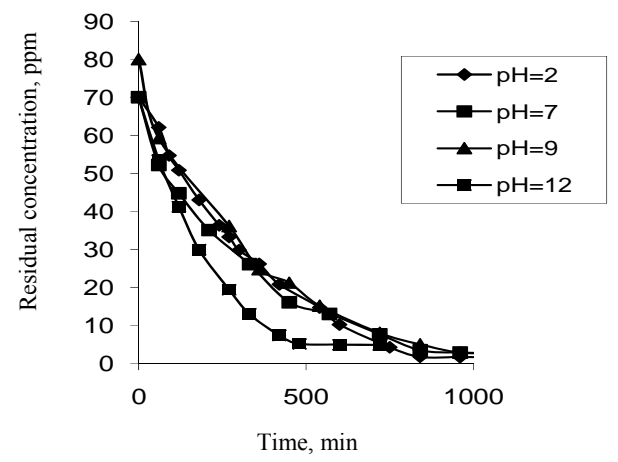

Figure 4. Residual concentration- time plots of tolonium chloride at various bufferic $\mathrm{pH}$ by use of optimum amount of anatase $\mathrm{TiO}_{2}(\mathrm{~V}=20 \mathrm{~mL})$

A plot of $\ln \left(\mathrm{C}_{0} / \mathrm{C}_{\mathrm{t}}\right)$ versus time lead to a straight line, the slope of which upon linear regression equals the observed first-order rate constant of photodegradation $k_{\text {obs }}$ (Figure 5 , Table 1).

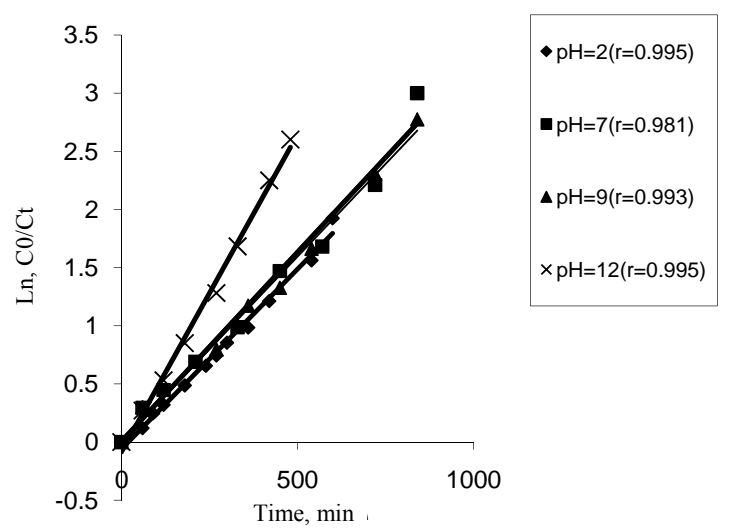

Figure 5. Kinetics of the tolonium chloride degradation $\left(\ln \left(\mathrm{C}_{0} / \mathrm{C}_{\mathrm{t}}\right)\right.$ vs. Time $)$ at various buffer $\mathrm{pH}$ 
Table 1. Kinetic parameters in photodegradation of tolonium chloride at various buffer $\mathrm{pH}$ in the presence of anatase titanium dioxide

\begin{tabular}{ccccc}
\hline Kinetic parameters & $\mathrm{pH}=2$ & $\mathrm{pH}=7$ & $\mathrm{pH}=9$ & $\mathrm{pH}=12$ \\
\hline $\mathrm{k}_{\mathrm{r}}, \mathrm{mg} . \mathrm{min}^{-1} \cdot \mathrm{L}^{1}$ & 0.46 & 0.77 & 0.46 & 1.38 \\
$\mathrm{k}_{\mathrm{obs}}, \mathrm{min}^{-1}$ & $2.9 \times 10^{-3}$ & $3.3 \times 10^{-3}$ & $3.2 \times 10^{-3}$ & $5.2 \times 10^{-3}$ \\
$\mathrm{t}_{1 / 2}, \mathrm{~min}$ & 239 & 210 & 216 & 133 \\
\hline
\end{tabular}

The tolonium chloride adsorption on catalyst surface can be explained by LangmuirHinshelwood (L-H) kinetic mode ${ }^{25-27}$. Modified to accommodate the reaction occurring at a solid-liquid interface. In this model the rate of reaction is proportional to the surface coverage $\theta$ :

$$
\theta=\frac{K C_{0}}{1+K C_{0}+K_{s} C_{s}}
$$

Where $K$ is the adsorption coefficient of substrate; Ks, the adsorption coefficient of solvent; $C_{0}$, the initial concentration of substrate and $C_{s}$ solvent concentration. The rate of photodegradation can then be written as a single-component L-H kinetic rate equation as following in which $k_{r}$ is the apparent reaction rate constant occurring at catalyst surface.

$$
\text { Rate }=R=\frac{-d c}{d t}=k_{r} \theta=k_{r} \frac{K C_{0}}{1+K C_{0}+K_{s} C_{s}}
$$

If $\mathrm{K}_{\mathrm{A}}$ is defined as:

The rate expression will be as:

$$
K_{A}=\frac{K}{1+K_{s} C_{s}}
$$

$$
\text { Rate }=R=\frac{-d c}{d t}=k_{r} \theta=k_{r} \frac{K_{A} C_{0}}{1+K_{A} C_{0}}
$$

And ultimately the equation $1 / \mathrm{R}$ in $1 / \mathrm{C}_{0}$ will be obtained:

$$
\frac{1}{R}=\frac{1}{k_{r} K_{A} C_{0}}+\frac{1}{k_{r}}
$$

The linear plots of $1 / \mathrm{R}_{\mathrm{L}-\mathrm{H}}$ versus $1 / \mathrm{C}_{0}$ for tolonium chloride on at various buffer $\mathrm{pH}$ is shown in Figure 6, which confirms the L-H model. In range of used concentration, photodegradation kinetic is in agreement to L-H model.

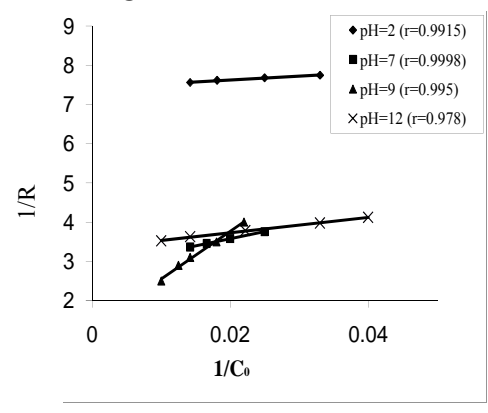

$1 / \mathrm{C}_{0}$

Figure 6. The plots of $1 / \mathrm{R}$ vs. $1 / \mathrm{C}_{0}$ at various buffer $\mathrm{pH}$ (Langmuir-Hinshelwood kinetics for degradation of tolonium chloride in the presence of anatase $\mathrm{TiO}_{2}$ ) 
As seen in Table 1, observed photodegradation rate constant, $\mathrm{k}_{\mathrm{obs}}$ (related to total reaction) and apparent reaction rate constant, $\mathrm{k}_{\mathrm{r}}$ increase while dye degradation half time, $t_{1 / 2}$ decreases as solution $\mathrm{pH}$ is raised. The maximum value of $\mathrm{k}_{\mathrm{obs}}$ and $\mathrm{k}_{\mathrm{r}}$ is related to bufferic $\mathrm{pH}$ of 12. A comparison between photodegradation rates of tolonium chloride at current work with ones previously reported under medium pressure irradiation using degussa titanium dioxide at non-bufferic $\mathrm{pH}$ is performed in Table 2.

Table 2. A comparison between photodegradation rates of tolonium chloride at different two conditions

\begin{tabular}{ccccc}
\hline Phodegradation rate, $\mathrm{k}_{\text {obs }}$ & $\mathrm{pH}=2$ & $\mathrm{pH}=7$ & $\mathrm{pH}=9$ & $\mathrm{pH}=12$ \\
\hline${ }^{\mathrm{a}} \mathrm{Ref}^{16}, \mathrm{k}_{\text {obs }} \min ^{-1}$ & - & $6.0 \times 10^{-2}$ & $(6.0-7.0) \times 10^{-2}$ & - \\
${ }^{\mathrm{b}}$ Present study, $\mathrm{k}_{\text {obs }} \min ^{-1}$ & $2.9 \times 10^{-3}$ & $3.3 \times 10^{-3}$ & $3.2 \times 10^{-3}$ & $5.2 \times 10^{-3}$ \\
\hline
\end{tabular}

${ }^{a}$ Refers to condions: Degussa $\mathrm{TiO}_{2} ; 125 \mathrm{~W}$ medium pressure mercury lamp; non-bufferic medium.

${ }^{b}$ Refer to conditions: anatase $\mathrm{TiO}_{2}(99.9 \%)$; $400 \mathrm{~W}$ high pressure mercury lamp; bufferic medium

Finally as seen in Table 2, the order of photodegradation rates of tolonium chloride based on conditions is as degussa titanium dioxide/medium pressure irradiation/non-bufferic $\mathrm{pH}>$ anatase titanium dioxide/high pressure mercury lamp/bufferic $\mathrm{pH}$. The plots of $1 / \mathrm{R}$ versus $1 / \mathrm{C}_{0}$ show that rate are decreased with increase of the initial concentration while in the presence of degussa type titanium dioxide the rate increase with increase of dye concentration and after a maximum is decreased. A comparison between the apparent reaction rate constants, $k_{r}$ at two conditions in Table 2 is not possible because this parameter has not been reported previously. This observed different between observed rates, $\mathrm{k}_{\mathrm{obs}}$ at two conditions may be related to a) more photoactivity of degussa titanium dioxide with respect to anatase titanium dioxide b) bufferic media in our current work that causes covering the surface of photocatalyst leading to reduction of the active sites for degradation. Also the current work indicates the optimum amount of catalyst is dependent to $\mathrm{pH}$ and may be different in different $\mathrm{pH}$.

\section{Conclusion}

In this research kinetic study of photodegradation of tolonium chloride at various bufferic $\mathrm{pH}$ of 2, 7, 9 and 12 in aqueous solution was presented. The effect of some physicochemical parameters such as initial concentration of dye, catalyst amount and reaction time on photocatalytic degradation has been investigated in a photo-reactor cell containing high pressure mercury lamp to obtain the optimum conditions in each bufferic $\mathrm{pH}$ at constant temperature. A complete spectrophotometric kinetic study of Tolonium chloride under high pressure irradiation at buffer media was performed and compared with previous Degussa type titanium dioxide phodegradation of the titled compound.

\section{References}

1. Freeman H M, Incinerating Hazardous Wastes, Technomiv Publishing Co., Lancaster, PA, 1988, p. 375.

2. Mills B, Filtr Separat., 1995, 32, 147-152.

3. Yang Y C, Berg F J, Szafraniec L L, Beavdry W T, Bunton C A and Kumar A, J Chem Soc Perkin Trans. 2, 1997, 607-613.

4. Yang Y C, Baker J A and Richardward J, Chem Rev., 1992, 92, 1729-1743.

5. Franke S, Franz P, Warnke W, der Militarchemie L and Militarverlag D, Berlin, 1976.

6. Houas A, Bakir I, Ksibi M and Elaloui E, J Chim Phys., 1999, 96, 479.

7. Patil S S and Shinde V M, Environ Sci Technol., 1988, 22, 1160. 
8. $\quad$ More A T, Vira A and Fogel S, Environ Sci Technol., 1989, 23, 403.

9. $\quad$ Slokar Y M and Le Marechal A M, Dyes Pigment, 1998,37, 335.

10. Fujishima A, Rao T N and Tryk, D A, J Photochem Photobiol C: Photochem Rev., 2000, 1, 1-21.

11. Mills A and Hunte S L, J Photochem Photobiol A: Chem., 1997, 108, 1-35.

12. Fox M A and Dulay M T, Chem Rev., 1993, 93, 341-357.

13. Hager S, Bauer R and Kudielka G, Chemosphere, 2000, 41(8), 1219-1225.

14. Kamta P V, J Phys Chem B, 2002, 106, 7729-7744.

15. Hoffman M R, Martin S T, Choi W and Bahnemann D W, Chem Rev., 1995, 95, 69-96.

16. Singh H K, Saquib M, Haque M M and Muneer M, Chem Engin J., 2008, 136, 77-81.

17. Habibi M H, Zeini Isfahani A, Mohammadkhani N and Montazerozohori M, Monat Fur Chem., 2004, 135, 1121-1127.

18. Habibi M H, Khaledisardashti M and Montazerozohori M, Ann Chim., 2004, 94(5-6), 421-428.

19. Montazerozohori M, Karami B, Habibi M H , Feres Environ Bull., 2007, 16(1), 44-49.

20. Montazerozohori M, Habibi M H, Joohari S and Khodadostan V, Ann Chim., 2007, 97(10), 1015-1026.

21. Wu T, Lin T, Zhao J, Hidaka H and Serpone N, Environ Sci Technol., 1999, 33, 1379-1387.

22. Augugliaro V, Palmisano L, Schiavello M, Sclafani A, Marchese L, Martra G and Miano F, Appl Catal., 1991, 69, 323 -340.

23. Zhao M Y, Chen S F and Tao Y W, J Chem Tech Biotechnol., 1995, 64, 339-344.

24. Hasnat M A, Siddiquey I A and Nuruddin A, Dyes Pigments, 2005, 66, 185-188.

25. Junny B and Pichat P, Langmuir, 1991, 7, 947-954.

26. Langmuir I, Trans Faraday Soc., 1921, 17, 621.

27. Matthews R W, J Chem Soc Farad Trans. 1, 1989, 85, 1291. 


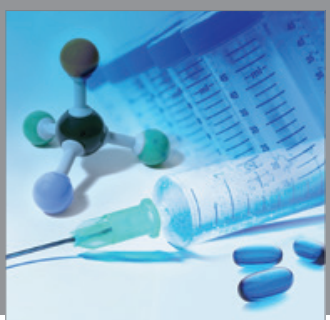

International Journal of

Medicinal Chemistry

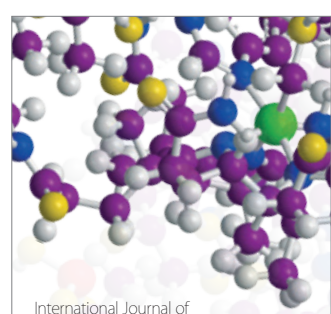

Carbohydrate Chemistry

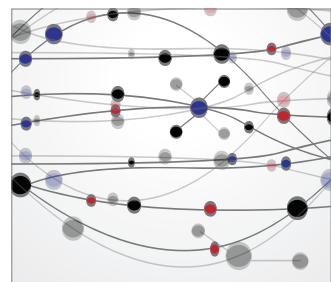

The Scientific World Journal
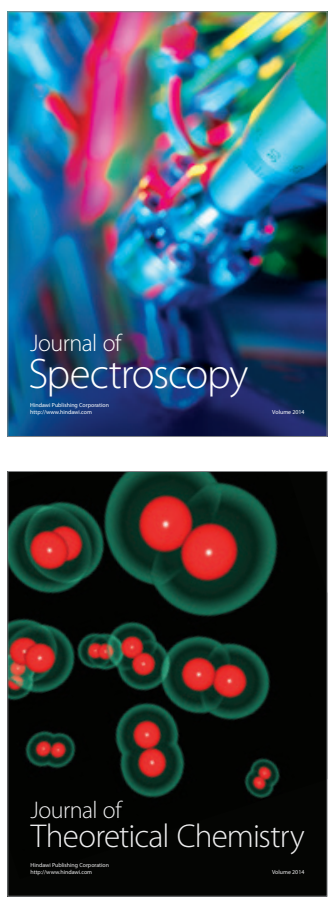
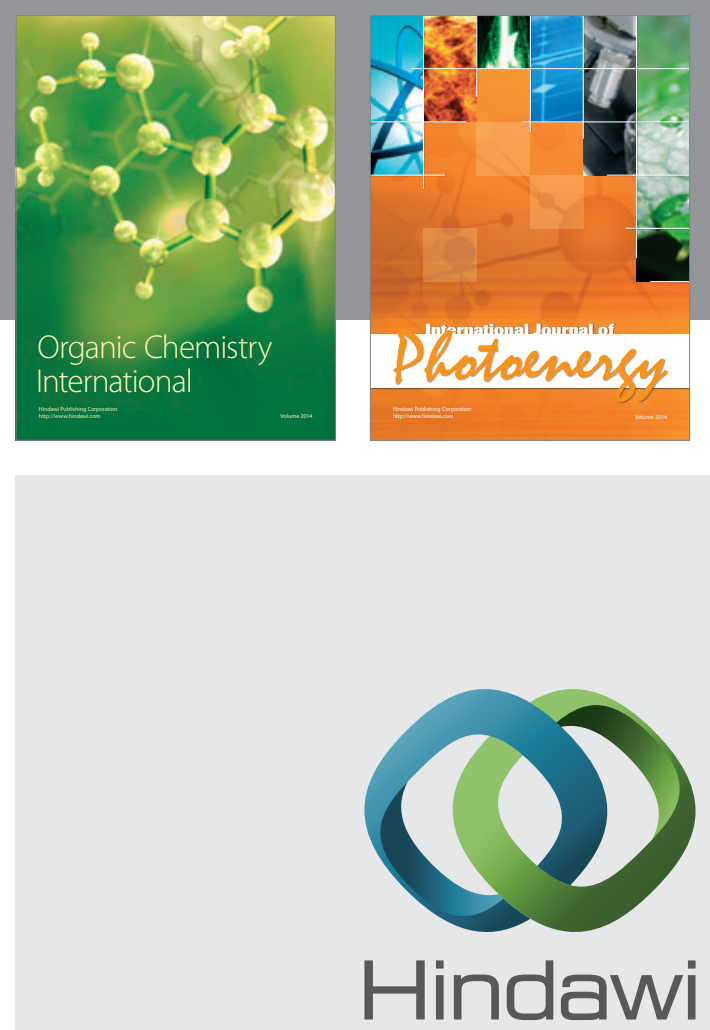

Submit your manuscripts at

http://www.hindawi.com
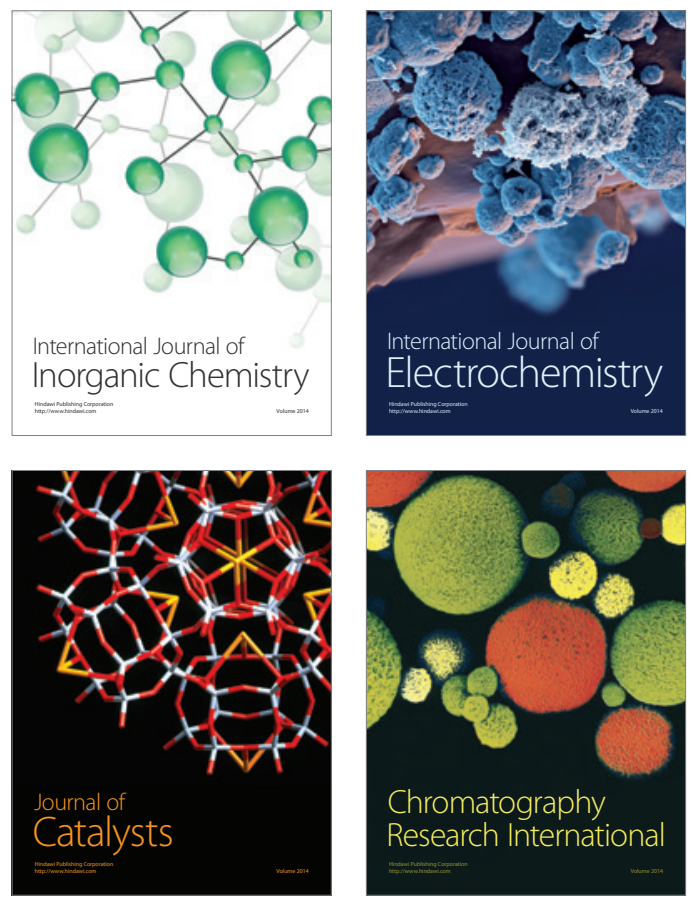
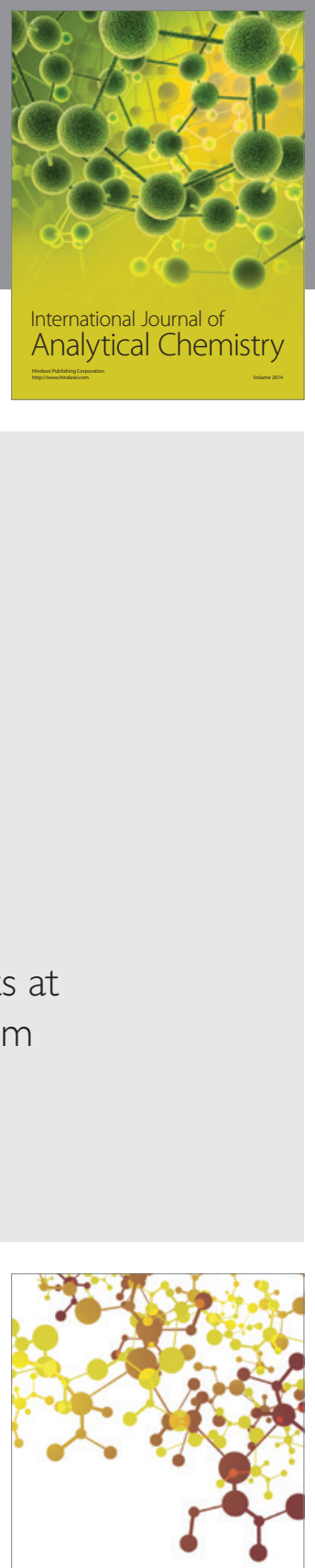

Journal of

Applied Chemistry
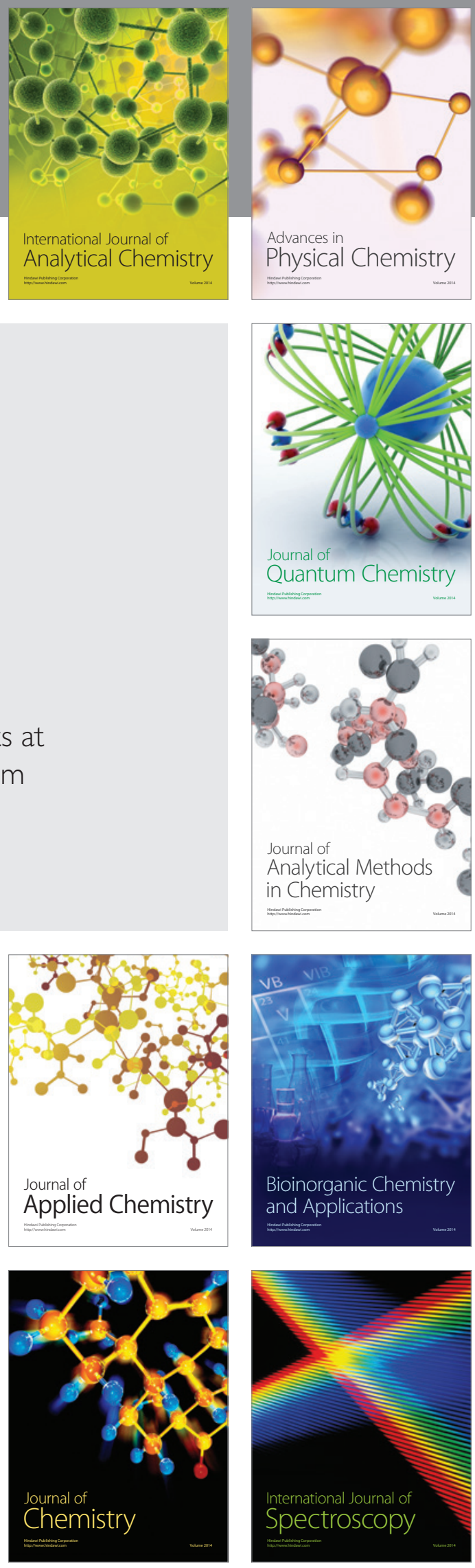